Journal of

Molecular Microbiology and Biotechnology

Aerts, A.M. 243

Aso, Y. 235

Bermúdez-Humarán, L.G. 259

Billaudel, S. 255

Cammue, B.P.A. 243

Cheng, F. 248

Chobert, J.-M. 255

Collins, B. 226

Cotter, P.D. 226

Dalgalarrondo, M. 255

De Vuyst, L. 194

Demnerova, K. 259

Drider, D. 193, 259

Duquesne, S. 200

Emanuelsen, L. 210
Field, D. 226

Fimland, G. 204

François, I.E.J.A. 243

Haertlé, T. 255

Hill, C. 226

Janiszewska, J. 220

Kristiansen, P.E. 210

Langella, P. 259

Leroy, F. 194

Li, Q.-T. 243

Meert, E.M.K. 243

Nagao, J. 235

Nakayama, J. 235

Nazef, L. 259

Nissen-Meyer, J. 210
Oppegård, C. 210

Peduzzi, J. 200

Petit, V. 200

Prévost, H. 259

Rebuffat, S. 200

Rihakova, J. 259

Rogne, P. 210

Ross, R.P. 226

Saris, P.E.J. 248

Shioya, K. 235

Sitohy, M. 255

Sonomoto, K. 235

Takala, T.M. 248

Thevissen, K. 243

Urbanczyk-Lipkowska, Z. 220

\title{
Subject Index Vol. 13, No. 4, 2007
}

Antibacterial peptides 220

Antimicrobial peptides 210, 226

Antiviral activity 255

Ascorbic acid 243

Bacteriocins 194, 210

-, food application 194

-, production 194

-, purification 194

Candida albicans 243

Carnobacterium divergens V41 259

Cytomegalovirus 255

Dendrimeric peptides 220

Divercin RV41 259

- -, antimicrobial activity 259

Escherichia coli 200
Esterification 255

Glucosylceramide 243

Immunity proteins 210

Iron siderophore receptors 200

Lactic acid bacteria 194

- _ - , antimicrobial potential 194

Lacticin 3147226

Lactococcus lactis 259

Lantibiotics 226, 235

Microcins 200

Milk 255

Nisin 248

- controlled expression system 259

Non-sequential pharmacophore 220

Nucleotide peptide 200
Peptic peptides 255

Peptide engineering 226, 235

Polylysines 255

Post-translational modification 235

Proteins 255

Random mutagenesis 226

Raphanus sativus antifungal plant defensin 243

Rapid Translation System 248

Reactive oxygen species 243

Siderophore peptide 200

Small unilamellar vesicle 243

Two-peptide bacteriocins 210

Unusual amino acid 235 